\title{
Adam, ubi es? : het burgerlijk procesrecht als juridische wetenschap met Europese allure
}

Citation for published version (APA):

van Rhee, C. H. (1999). Adam, ubi es? : het burgerlijk procesrecht als juridische wetenschap met Europese allure. Kluwer. https://doi.org/10.26481/spe.19990520rr

Document status and date:

Published: 20/05/1999

DOI:

10.26481/spe.19990520rr

Document Version:

Publisher's PDF, also known as Version of record

\section{Please check the document version of this publication:}

- A submitted manuscript is the version of the article upon submission and before peer-review. There can be important differences between the submitted version and the official published version of record.

People interested in the research are advised to contact the author for the final version of the publication, or visit the DOI to the publisher's website.

- The final author version and the galley proof are versions of the publication after peer review.

- The final published version features the final layout of the paper including the volume, issue and page numbers.

Link to publication

\footnotetext{
General rights rights.

- You may freely distribute the URL identifying the publication in the public portal. please follow below link for the End User Agreement:

www.umlib.nl/taverne-license

Take down policy

If you believe that this document breaches copyright please contact us at:

repository@maastrichtuniversity.nl

providing details and we will investigate your claim.
}

Copyright and moral rights for the publications made accessible in the public portal are retained by the authors and/or other copyright owners and it is a condition of accessing publications that users recognise and abide by the legal requirements associated with these

- Users may download and print one copy of any publication from the public portal for the purpose of private study or research.

- You may not further distribute the material or use it for any profit-making activity or commercial gain

If the publication is distributed under the terms of Article $25 \mathrm{fa}$ of the Dutch Copyright Act, indicated by the "Taverne" license above, 
ADAM, UBI ES? 



\section{ADAM, UBI ES?}

Het burgerlijk procesrecht als juridische wetenschap met Europese allure

REDE UTTGESPROKEN

BIJ DE AANVAARDHNG VAN HLE AMBT VAN

HOOGLERAAR IN HET RECHT,

IN HET BUZONDER DE EUPOPESE RECHTSGESCHIEMENIS,

AAN DE UNIVERSITEIT MAASTRICHT

OP DOMDERDAG 20 MHI 1999

DOOR C.H. VAN RHEE

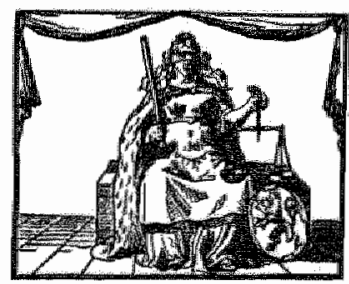

MAASTRICHT

1999 
Uitgever: Kliwwer, Deventer

ISBN 9026835035

(6) $1999, \mathrm{C} . \mathrm{H}$. vint khee

Alle rechten voobehouden. Niets uit deze uitgave mag worden verveelwoudigd, opgeshgen in een geattomatiserd gegevensbestand, of openbar gemakt, in enge vorm of op enige wijae, hetaj elektronisch, mechanisch, door fotokopieen, opnamen, of enige andere manis, zonder woonfgande schriftelike toestemming van tuigeverij Kluwer.

Voof zover het maken van kopieèn uit dege uitgave is toegestan op grond van artikel $16 b$ Auteurswet 1912 jo, het Besluir van 20 jun $1974,54 b .351$, zoals gewijzgd bij laet $\mathbb{B}$ eshit van 23 augustus 1985, Stb. 471 , en artikel 17 Auteurswet 1912, dient men de darvoor verschuldigde wettelike vergoedingen te voldoen an de Stichting Reprorecht (Postbus 882. 1180 AW Amstelveen). Voor her overnemen wan gedeelte(n) uit dexe vitgave in bloemlezingen, readers en andere compilatiewerken (artikel 16 Auteurswet 1912) dient men zich tot de uitgever te wetaden. 


\section{Mignheer de Rector Magnificus}

Danes en Heren

\section{INLEIDING}

'Nedergedaald ter helle' In een opstel met deze titel vestigde mijn Amsterdamse collega $\mathbb{E}$ J.H. Schrage onlangs de andacht op het feit, dat het procesrecht in het Paradijs is ontstaan, althans, wanneer wij de Middeleeuwse en vroegmoderne juristen mogen geloven.' De mij intussen zeer dierbaar geworden jurist Philips Wielant, afkomstig uit het mij eveneens dierbarte Vlaamse land, zegt er in zijn Practijke Civile het volgende over: "God en wilde Adam niet condempneren sonder hem eerst op te roepen [...] ende sonder hem te hooren [...]." Met andere woorden, God weroordeelde Adam niet pardoes tot het eten van brood in het zweet zijns aanschijns, maar nam een aantal vormen in acht alvorens hij de zware straf oplegde, waaronder wij nog dagelijks zuchten. Ook Eva werd gehoord alvorens haar en haar zusters de smart deelachtig werd die aan het baren van kinderen is verbonden. Slechts de slang werd zonder een vormelijke procedure veroordeeld. Een verklaring hierwoor biedt het boek Genesis niet, maar gelukkig kont de Statenvertaling ${ }^{3}$ ons in dit opzicht te hulp. In een verklarende noot wordt opgenerkt dat het horen van de slang achterwege kon blijven, aangezien het serpent als werktuig van de duivel had gefunctioneerd en de duivel geen excuus had, een argument dat de fair frialtoets van artikel 6 van het Europees Verdrag tot bescherming van de Rechten van de Mens, ware het van toepassing geweest, zeer zeker niet zou hebben kunnen doorstaan.

De regel dat procespartijen in een juridische procedure dienen te worden opgeroepen en gehoord, is een voorbeeld van een vormvereiste, een forma-

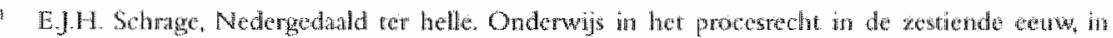

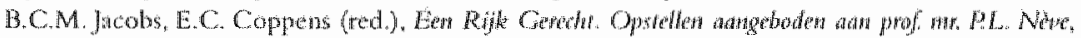

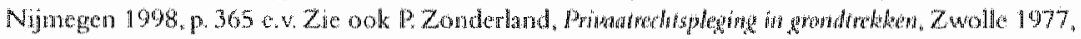
p. $12(100065)$

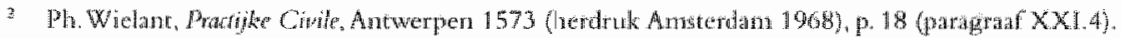

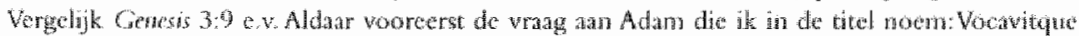

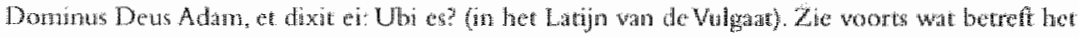

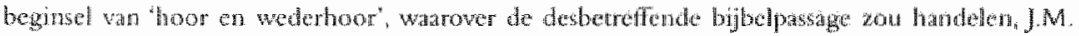

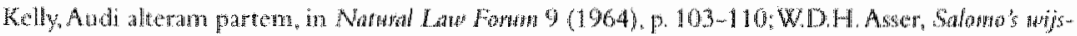

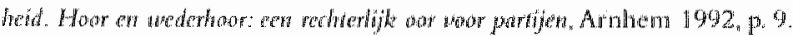

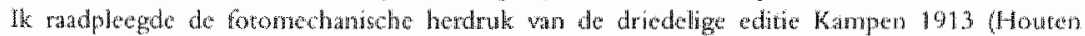
$1980)$. 
liteit. Een samenhargend geheel van dergelike formaliteiten, die juridische procedures van bet begin tot het einde regelen, zou ik willen aanduiden als procestecht in engere zin, het eigenlijke formele recht. De regels met betrekking tot de rechterlijke organisatie (inclusief competentie), die tot het procesrecht in bredere zin kunnen worden gerekend, vallen buiten deze definitie." Met de rechterlijke organisatie zal ik mij niet bezighouden. De reden hiervoor is, dat ik vandaag het procesrecht vooral als Europese discipline wil benaderen. Vraagstukken betreffende de rechterlijke organisatie lenen zich minder voor eèn dergelijke benadering, angezien zjj een zeer nauwe verbondenheid met de nationale rechtssfeer vertonen. ${ }^{5}$

Het procesrecht moet goed worden onderscheiden wan het materiele recht. Het materiele recht heeft voomamelijk de inhoud van rechten en plichten van rechtssubjecten tot object, terwijl het procesrecht bovenal bepaalt op welke wijze deze rechten en plichten in een juridische procedure dienen te worden vastgesteld, geeffectueerd dan wel vormgegeven. ${ }^{6} \mathrm{R}$ ond 1900 heeft een Oostenrijks jurist het onderscheid tussen materieel en formeel recht op treffende wijze verwoord. 'Materielles Recht und Prozess', zo zegt hij, "verhalten sich zu einander whe der Gedanke zu seiner Ausfihrung." Nog fraaier zegt Karl Marx het: "[...] der Prozess ist [...] die Lebensart des Gesetzes, also die Erscheinung seines innern Lebens."

Het bovenstaande doet vermoeden, dat het procesrecht meer is dan een louter technisch instrument in de handen van praktijkjuristen. Zo dit inderdaad het geval is, kan het niet dan opmerkelijk worden genoemd, dat het met de wetenschappelijke bestudering van dit rechtsgebied in veel landen lange

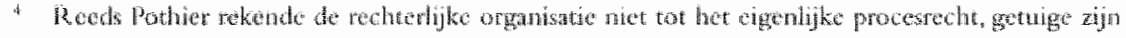

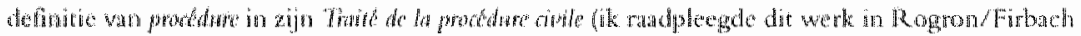

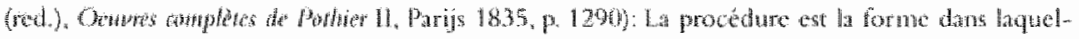

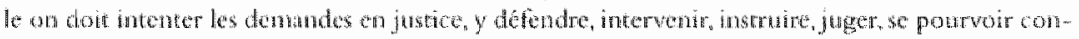

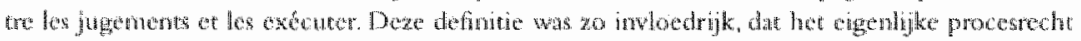

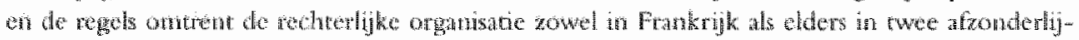

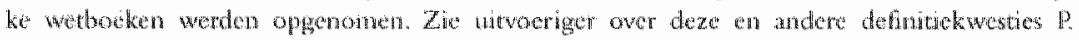

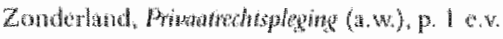

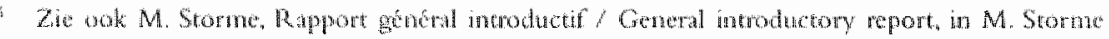

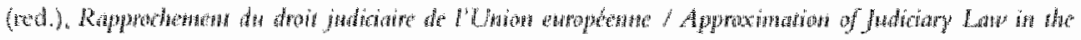

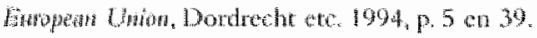

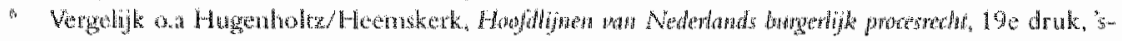
Com

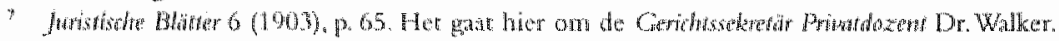

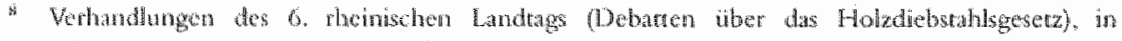

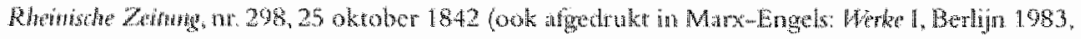
P. 145$)$. 
tijo matig gesteld is geweest. In Nederland en Belgie is pas de latste decen nia een opleving op dit terrein te constateren. Wat betreft de geschedenis wan het burgerlijk procesrecht, kan gewezen worden op de bijdrage wan R.C. wan

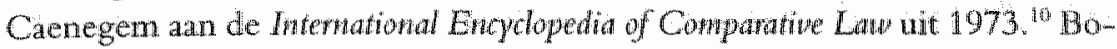
vendien verschenen in onze streken rechtshistorische studies nate de procedure van afzonderljke rechtbanken tijdens het ancien rome. Herbig ging het vooral om het recht zoals dat in de praktijk werd toegepast, de zogenoemd "stijl" van de verschillende rechtbanken. Hoewel men oorsponkalik nog wan de onjuiste gedachte uitging, dat dit praktjkrecht wit normatieve bromen kon worden gekend, luidden auteurs als J. van Rompaey een nujns inziens gelukkiger tijdpark in toen zij de studie van het procesrecht aan de thand wan de archiestukken van de verschillende hoven van justitie ter hand namen." Van nog recenter datum is de belangstelling voor de geschiedenis wan de (fundamentele) beginselen van procesrecht. De oratie van mijn Leidse leermeester J.M.J. Chorus over de lijdelijkheid van de burgerlijke rechter kan hier als het begimpunt worden beschouwd. "2 Ook W.D. Asser toont historische belangstelling in zijn Nijmeegse oratie over hoor en wedewhoor. ${ }^{13}$

De geringe aandacht voor het procesrecht alls wetenschap houdt verband. met de gedachte, dat dit rechtsgebied voor serieuze wetenschappelijke bestudering nawwelijks in aanmerking komt. ${ }^{14}$ Eigenlijk is Duitiland het enige Europese land dat en wetenschappelijke procesrechtelijke traditie kent. ${ }^{15}$ luet universitaire onderwijs blijkt deze traditie echter niet altijd het gewenste

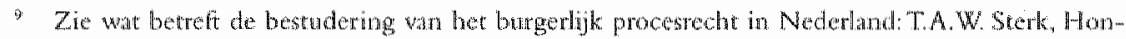

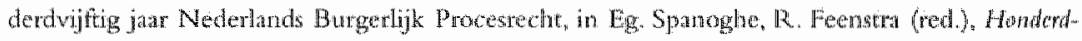

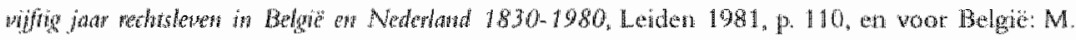

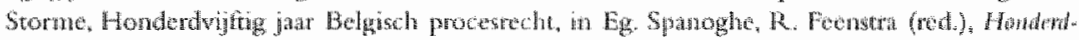

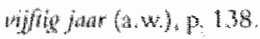

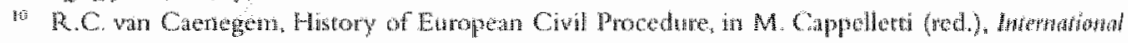

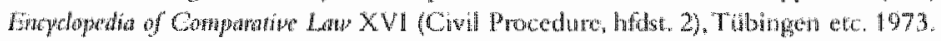

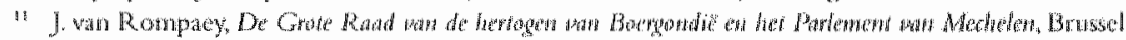
1973.

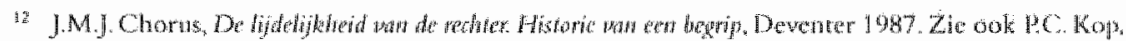

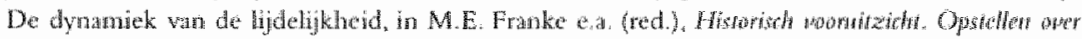

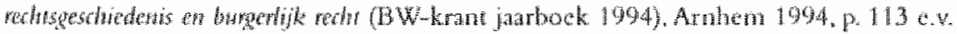

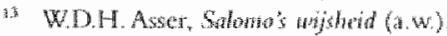

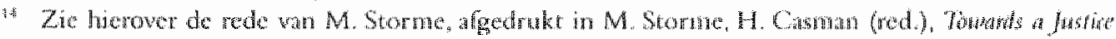

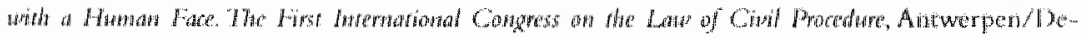

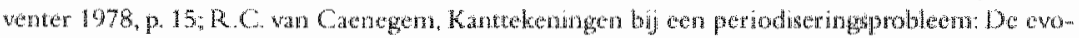

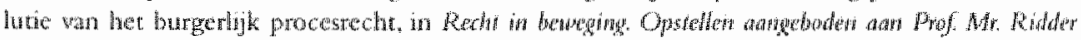

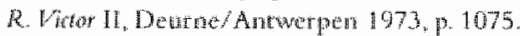

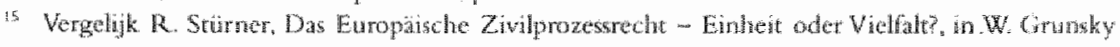

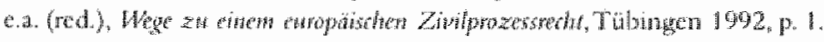


effect the hebben gehad. G. Baumgartel, de hoogleraar die in de jaren zeventig van deze eeuw belast was met een onderzoek naar de oorzaken van de lange dwur van processen in Duitsland, merkte bijvoorbeeld in 1971 op: "Es ist aber wohl kein Geheimnis, dass gerade das Zivilprozessrecht in der Ausbildung - jedenfalls an der Universität - viel zu kurz kommt." Dit was overigens geen nieuw geluid, want problemen op het gebied van het procesrechtelijk onderricht aan de universiteit zijn van alle tijden. In het verleden kon het gebeuren, dat studenten de universiteit verlieten zonder enige kennis van het procesrecht, getuige onder andere de Orda Iudiciarius van Aegidius de Fuscarariis uit 1260-1266. Aan het begin wan zijn Ordo merkt deze auteur op, dat hij zijn werk niet alleen schreef voor zijn studenten, maar ook 'ad eruditionem noworum advocatorum militantium in iure canonico, qui licet periti in jure existant, ignorantes tamen practicam causas nesciunt ordinare [...]" (dat wil zeggen, ter lering van nieuwe advocaten die dienen in het Kanonieke recht, dewelken, hoewel zij als kundig in het recht naar voren komen, toch in hun onbekendheid met de praktijk geen zaken kunnen instrueren [...]). ${ }^{77}$ Momenteel kan woor de meeste Europese landen niet langer worden gesteld, dat studenten hun universiteit verlaten zonder enige kennis van het procesrecht. Immers, aan bijna elke Europese universiteit maakt het procesrechtelijk onderricht een vast onderdeel van het curriculum uit. Echter, daarmee is dit vakgebied als universitaire discipline geen rustig bezit geworden. $Z_{0}$ bepleitten Oostenrijkse studenten nog niet zolang geleden zelfs de afschaffing ervan, aangezien zij van mening waren, dat het niet bijdroeg aan hun wetenschappelijke vorming. Scholing in het procesrecht zou beter an de praktijk kunnen worden overgelaten. ${ }^{18}$ De Oostenrijkse klachten moeten serieus worden genomen. Echter, de omstandigheid dat de inhoud van het vak procesrecht op dit moment mogelijkerwijze niet of minder bijdraagt aan de wetenschappelijke vorming van de student, draagt mijns inziens niet de conclusie dat procesrechtelijk onderwijs dient te worden afgeschaft. Eerder dient deze klacht te leiden tot een gedeeltelijke heroverweging wat betreft de inhoud van het vak, zowel op het gebied van het universitair onderzoek als op dat van het universitair onderricht.

Op het gebied van het onderwijs concentreert men zich thans vooral op nationaal procesrecht, warbij veelal de nadruk wordt gelegd op een exegese

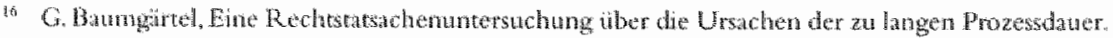

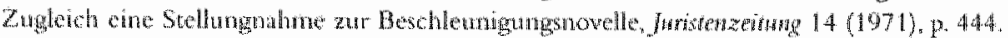

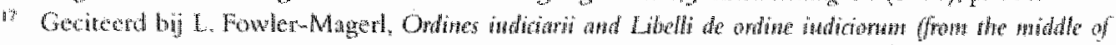

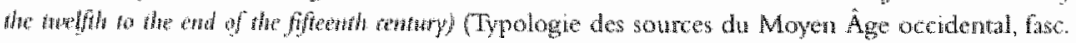

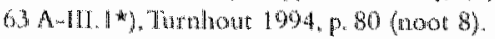

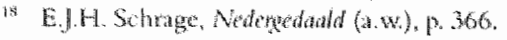


vam het Wetboek van Burgerlijke Rechtswordering of een gelijkatrdige regeling, aangevuld met relevante jurisprudentie en toepasseligke supranationale regelgeving. Ook op het gebied van het onderzoek komt men een dergelijke benadering regelmatig tegen. Deze eenzijdige gerichtheid op de technische kanten van de eigen, nationale procedure lijkt mij minder passend voor onderzoek en onderricht dat de pretentie heeft wetenschappelijk wan aard te zijn. Wetenschappelijk onderzoek en onderricht dient zich mijns inziens tovens te richten op andere onderwerpen. Ik denk hierbij bijvoorbeeld aan onderwerpen op het gebied van de rechtsvergelijking en de rechtsgeschiedenis. ${ }^{19}$ Twee vragen van rechtsvergelijkende en rechtshistorische aard wil ik vandaag centraal stellen. Zij luiden:

1 In hoeverre kan het burgerlijk procesrecht worden opgevat als een internationale, Europese discipline?

2 Welke rol kunnen rechtsgeschiedenis en rechtsvergelijking spelen bij het vormgeven van toekomstig burgerlijk procesrecht?

Echter, alvorens ik tot behandeling van deze vragen overga, wil ik bezien welke factoren (mede) een rol speelden in de vorming van het niet-wetenschappelijke imago van het procesrecht. Behandeling van deze vraag biedt mij de gelegenheid een aantal hoofdmomenten uit de procesrechtsgeschiedenis onder uw aandacht te brengen die ik nodig zal hebben in het vervolg van mijn betoog.

\section{HET PROCESRECHT: EEN WETENSCHAPPELIKE DISCHPLINE?}

In 1927 publiceerde Charles Homer Haskins een boek met de titel The Renaissance of the furelfth century. ${ }^{20}$ Deze Renaissance van Haskins, die woorafgaat aan het tijdperk dat traditioneel met deze benaming wordt aangeduid, kenmerkt zich door een grote belangstelling voor de Romeinse oudheid, waaronder het Romeinse recht. Dit recht werd an een nauwgezet onderzoek onderworpen en bruikbaar gemaakt woor toepassing in de praktijk. De basistekst hierbij wormde de Romeinsrechrelijke wetgeving van de Byzantijnse keizer Justinianus, die in de zesde eeuw na Christus met behulp van nog ouder material werd samengesteld. Deze wetgeving geraakte in een latere periode bekend onder de benaming Corpus Imris Ciwilis.

Het Corpus Iuris Civilis bevat veel teksten van procesrechtelijke ard. Een

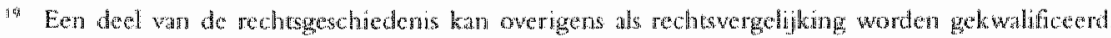

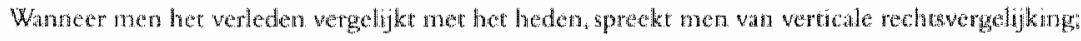
dit in tegenstelling tot horizontale rechtswergelijking, watbij men moderne stelsels met elkatr confrontert.

3. Cambritge 1927 . 
affonderlijke afdeling met een omvattende regeling van de procedure is er echter niet in terug te vinden ${ }^{21}$ Zonder wetenschappelijke arbeid was voor de middeleeuwse jurist met de Romeinsrechtelijke teksten betreffende procestechtelijke onderwerpen dan ook weinig aan te vangen. Immers, in de eerste plats moesten deze over het gehele Corphs Luris verspreide passages bijeen worden gebracht. Vervolgens dienden zij te worden geinterpreteerd en moesten zij op systematische wijze teboek worden gesteld. Dit was vooral ook nodig omdat de teksten in het Corpus luris betrekking hebben op verschillende procesvormen. Hoewell de meeste teksten de onder keizer Justinianus gebruikelijke procedure extra ordinem betreffen, komen we ook materiaal tegen dat handelt over oudere procedurevormen, zoals het formula-proces. Bovendien is niet altijd duidelijk welke procesvorm in een bepaalde tekst het uitgangspunt vormint.

Het resultaat van de inspanningen van de middeleeuwse juristen was, dat een geheel nieuwe procedure werd vormgegeven, die, afgezien van het Romeinsrechtelijke gedachtegoed, was gebaseerd op canones uit het tweede deel van het Decreet van Gratianus, het recht van steden in het noorden van Italië en recente passelijke decretale brieven. ${ }^{22}$ Gezien haar bronnen wordt de nieuwe procedure angeduid als de Romano-canonieke procedure.

Het geleerde Romano-canonieke procesrecht werd oorspronkelijk in kerkelijke sfeer toegepast. Dit gebeurde in het bijzonder bij een nieuw type kerkelijke rechtbanken, de zogenoemde officialiteiten. ${ }^{23}$ Deze officialiteiten kenden verspreiding in aanzienlijke delen van Europa en hadden een zeer ruime absolute competentie. Het gevolg hiervan was, dat grote groepen mensen met de Romano-canonicke procedure in aanraking kwamen. Dit bleef niet zonder gevolgen, mogelijkerwijze ook omdat het procesrecht bij de seculiere jurisdicties niet meer aan de eisen des tijds voldeed. Dit seculiere procesrecht wortelde in de samenleving van de vroege Middeleeuwen, hetgeen onder andere blijkt uit het gebruik van irrationele bewijmiddelen als het godsoordeel. Deze vroegmiddeleeuwse samenleving makte plats voor een samenleving met een ingewikkelder structuur ${ }^{24}$ die behoefte had aan een andersoortig procesrecht, een behoefte warin de Romano-canonieke procedure kon voorzien. Immers, de nieuwe procedure bood een aantal belangrijke

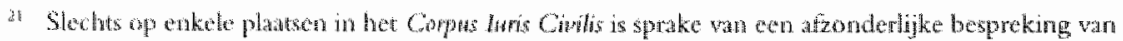

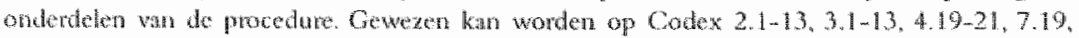

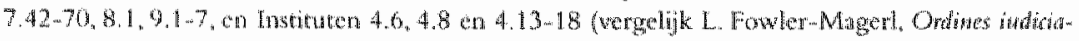
wii (a.w). p 28 (noot 39)

24 L. Fow

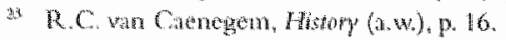

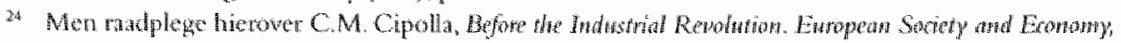
togk- 700, 2e dnk, Londen 1981. 
voordelen ten opzichte van de bestaande manier van procederen. $Z$ o stelde zij de rechter beter in stat gevallen van grote complexiteit te behandelen en bracht zij een betere balans tussen de activiteitem van rechter en partijen ${ }^{25} \mathrm{De}$ invloed van de Romano-canonieke procedure bij wereldlijke jurisdicties deed dan ook niet lang op zich wachten.

Zolang het Romano-canonieke procestecht werd toegepast binnen kerkelijke sfeer bestond een zekere mate van eenvormigheid op Europees niveau, zij het met enige plaatselijke varianten. ${ }^{20}$ Het Romano-canonieke procesrecht vormde daarmee een waar lus Conmune in de zin van een relatief uniform stelsel van procedureregels voor de gehele westerse Christenheid, ${ }^{27}$ Verhandelingen waarin dit vakgebied werd opgevat als een discipline van algemene strekking waren talrijk. ${ }^{28}$ Deze verhandelingen ontleenden hun wetenschappelijke karakter in hoge mate an de noodzaak de procedure vanuit haar Romeins- en canoniekrechtelijke bronnen te begrijpen, waardoor verwijzingen naar deze bronnen en de erop gebaseerde literatuur veelvuldig voorkwamen. Een goed voorbeeld vormt in dit opzicht het encyclopedische Speculum Judiciale van Guilelmus Durantis (overleden 1296). ${ }^{29}$ Dit Speculum, dat volgens M.A. von Bethmann Holweg het materiaal van de meer belangrijke procesrechtelijke geschriften in zich opnann net als de oceaan dit met de stromen doet, ${ }^{30}$ werd geschreven in de periode 1271-1276 en vormt een magistrale synthese van het procesrecht zoals dat in de dertiende eeuw zijn min of meer uiteindelijke vorm had gekregen. ${ }^{31}$ Dit werk zou vele eeuwen boven aan de lijst staan van de meest geciteerde werken over procesrecht. Zo heeft mijn. Doktorvater, Alain Wrijffels, aangetoond dat Durantis' Specaltm in de periode 1460-1580 het meest frequent aangehaalde werk bij de Grote Raad van Mechelen was. ${ }^{32}$

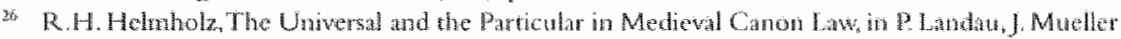

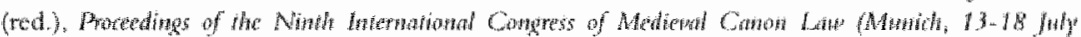
1992), Vatikaanstad 1997, p. 653 e.v.

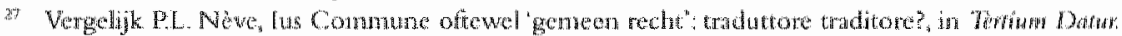

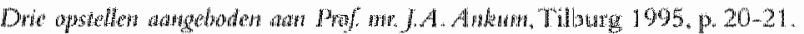

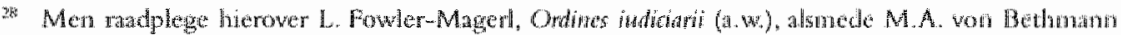

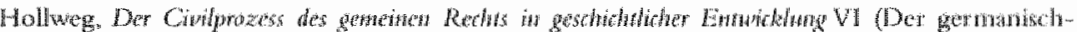
romanische Civilprozess in Mirtelatlect, Bonn 1874.

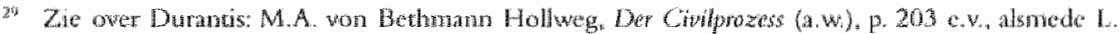

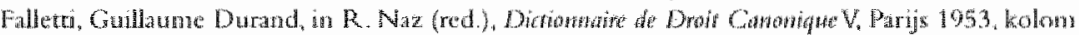
$1014 \mathrm{ew}$

w M.A. won Bethmann Follweg Der Civilprozess (a w.), p, 203

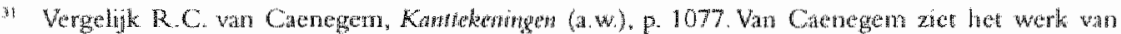
Durants als de afsluting van de formatiexe periode wan het geleerde procesteclut.

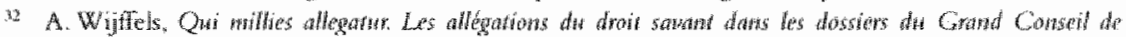

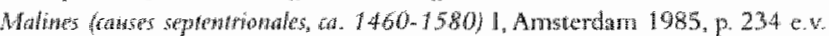


Toen de Romano-canonieke procedure buiten kerkelijke sferen werd toegepast, veranderde de procesrechtelijke literatuur van karakter. Bij de wereldlijke jurisdicties werd het geleerde proces namelijk niet in zijn geheel overgenomen, maar was sprake van een meer of minder vergaande mate van beïnvloeding van de seculiere procedure door het Romano-Canonieke model. Deze omstandigheid is een wan de redenen voor het bestaan van procesrechtelijke 'stijlen', dat wil zeggen bijzondere wijzen van procederen die eigen waren aan een bepaald gebied of een bepaalde rechterlijke instantie. Het gevolg wan het bestaan van deze 'stijlen' was, dat ook de literatuur over de wereldlijke procedure een plaatselijk karakter kreeg. Deze literatuur behandelde niet het ene Romano-canonieke grondpatroon, maar het procesrecht binnen een specifieke jurisdictie. ${ }^{\text {ts }}$ In onze streken vinden wij hiervan vele voorbeelden. In mijn inleiding sprak ik reeds over Philips Wielant. Deze auteur beschreef in zijn eerdergenoemde Practijke Civile voornamelijk de manier van procederen bij de Raad van Vlaanderen, de vorstelijke rechtbank van het graafschap Vlaanderen. Eenzelfde aanpak vertoont, om een ander voorbeeld te nemen, het werk van Gerard van W/assenaer, die het Hof van Utrecht centraal stelde. ${ }^{34}$ Toch ging deze anopak niet gepaard met een teruggang van het wetenschappelijke gehalte van de procesrechtelijke literatuur. ${ }^{35}$ Dit blijkt onder andere uit het feit dat de door de verscheidene auteurs behandelde procesrechtelijke 'stijlen' worden gerelateerd aan het Romano-canonieke grondpatroon. Uit het werk van Van Wassenaer blijkt dit door expliciete verwijzingen naar de bronnen van de Romano-canonieke procedure en de erop gebaseerde literatuur. Wielant haakt meer impliciet bij het Romano-canonieke gedachtegoed aan door op meerdere platsen te refereren aan 'de (civile) rechten', zonder overigens een vindplats te noemen. ${ }^{36}$ Het rechtswergelijkende element levert eveneens een belangrijke bijdrage aan het weten-

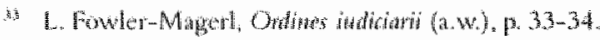

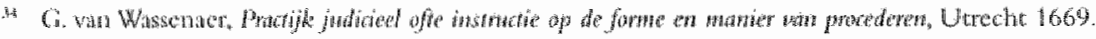

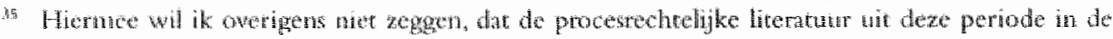

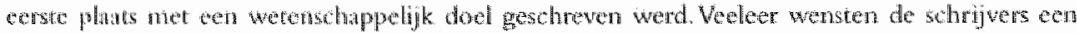

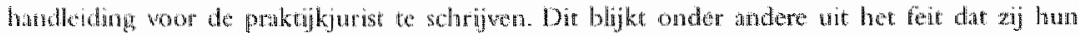

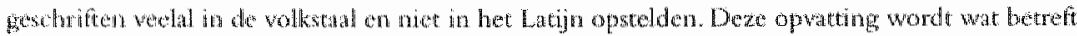

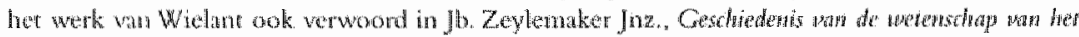

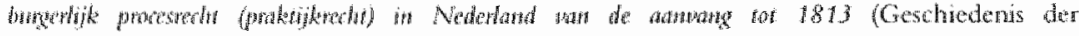

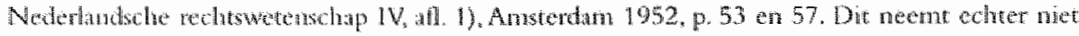

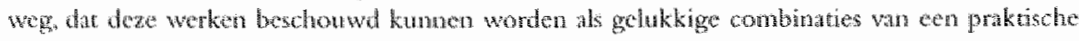
en cen meer wetenschapelike benadering.

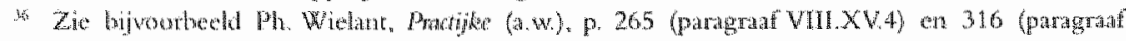
$1 \times \times x \cup 11.5)$ 
schappelijke karakter van werken als die wan Wielant en Van Wassenaer. ${ }^{37}$ Wielant vergelijkt het procesrecht bij de Raad van Vlaanderen regelmatig met de manier van procederen bij de Grote Raad van Mechelen, éen der hoogste hoven in de Nederlanden, ${ }^{38} \mathrm{en}$, in mindere mate, met de procedure wan het Parlement van Parijs, de hoogste vorstelijke rechtbank van het Franse koninkrijk. ${ }^{39}$ Ook Van Wassenaers blikveld is ruimer dan Utrecht. Hij blijkt immers een gedegen kennis te hebben van het procesrecht in Holland. to

De codificatieperiode eind $18^{\circ} /$ begin $19^{\circ}$ eeuw heeft het procesrecht van gezicht doen veranderen. Elementen die in het verleden het wetenschappelijke karakter van dit vakgebied bepaald hadden, verdwenen. Dit was in de eerste plaats een gevolg van de omstandigheid dat de rol van het geleerde recht was uitgespeeld; het werd tuitdrukkelijk als rechtsbron terzijde geschoven." Het Romano-canonieke procesrecht kon daardoor niet meer worden aangewend bij de interpretatie van positieve procesrechtelijke regels. Bovendien verviel de mogelijkheid van plaatselijke en regionale rechtsvergelijking. Codificatie bracht immers in veel gevallen een eenvormige procedure voor de gehele natie. Slechts internationale rechtsvergelijking bleef mogelijk. Aan deze rechtsvergelijking bestond echter minder behoefte dan an de rechtsvergelijking op regionale en plaatselijke basis in de voorafgaande periode. Immers, het praktische nut van, bijvoorbeeld, kennis betreffende de overeenkomsten en verschillen tussen de procedure van het Hof van Holland en die van het Hof van Utrecht was voor een jurist uit de Republiek evident; hij kon met zaken voor beide hoven worden geconfronteerd. Voor een jurist uit de periode na de codificatie was daarentegen het belang van kennis betreffende verschillen en overeenkomsten tussen nationaal en buitenlands procesrecht minder evident. Slechts het gegeven dat een nationaal procesrechtelijk stelsel in meer of mindere mate ontleend was an het buitenland kon het verdwijnen van het rechtsvergelijkende element uit de literatuur vertragen. Dit zien wij bijwoorbeeld in Nederland, war de procedure op Franse leest werd geschoeid. Daarmee bleef Frans procesrechtelijk materiáal lange tjjd wan emi-

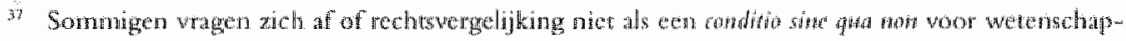

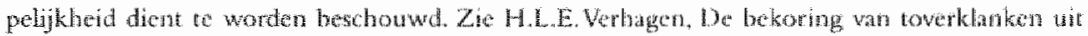

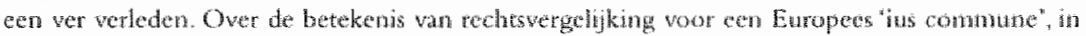

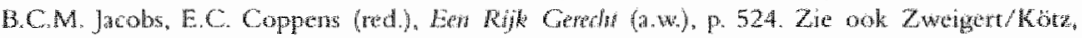

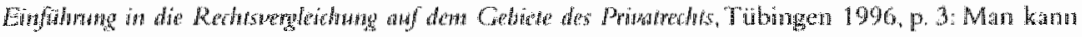
in der Tat zweifoln ob de blose Interpretation geticnder Gesete mit den iblichen Methoden

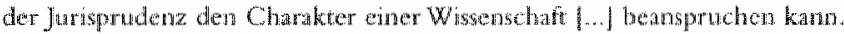

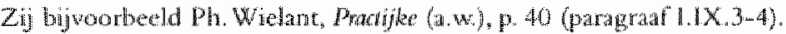

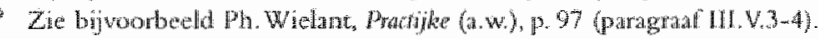

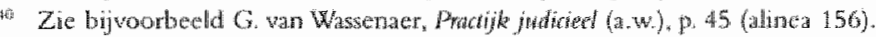

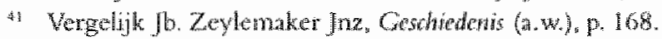


nent belang, N2 Narmate de tijd worderde en de ontwikkelingen verder afvoerden van het Franse woorbeeld, verdween echter de noodzaak van rechtsvergelijking. Rechtsvergelijkende activiteiten op procesrechteligk terrein werden wanaf dat moment eigenlijk alleen nog ondernomen indien plannen bestonden om tot hercodificatie van het procesrecht over te gaan. Dit kon echter niet verhinderen, dat cen benadering van het procesrecht ontstond die wij thans nog a antreffen in veel handboeken, waaronder de handboeken die ten grondslag liggen aan het universitaire onderwijs. In deze literatuur ontbreekt het rechisvergelijkende element vaak geheel. Het grootste gedeelte wan de in deze literatuur besloten informatie betreft beschrijvingen van het nationale procesrecht. Onder deze omstandigheden is het nier geheel onbegrijpelijk dat bij studenten de gedachte kan ontstaan, dat het procesrechtelijk onderwijs minder bijdraagt aan hun wetenschappelijke vorming. Als afgestudeerd jurist zullen deze studenten licht van mening zijn, dat het procesrecht een vakgebied is, dat woor serieuze wetenschappelijke bestudering nauwelijks in anmerking kont. Zo zij een wetenschappelijke carrière ambiëren, zullen zij die niet zo snel in het procesrecht zoeken. Het is zaak aan deze situatie spoedig een halt toe te roepen, aangezien juist op procesrechtelijk gebied momenteel vele interessante wetenschappelijke vragen spelen die nodig nader bestudeerd dienen te worden. Twee van deze wragen vermeldde ik in de inleiding. I $\mathrm{k}$ zal thans tot behandeling van de eerstvermelde vrag overgaan.

\section{PROCESRECHT: EEN INTERNATIONALE, EUROPESE DISCIPEINE?}

Over het karakter van het procesrecht wordt, net als overigens over het karakter van het materiële recht, verschillend gedacht. Sommigen zijn van mening dat dit rechtsgebied onlosmakelijk met de identiteit van een volk of natie verbonden is. De wijze warop dit rechtsgebied is vormgegeven, zou nutuwe samenhang vertonen met een aantal kenmerken van de groep personen warwoor het bedoeld is. Bij deze kenmerken wordt gedacht aan zaken als wolksaard, levensfilosofie en politieke overtuiging. ${ }^{43}$ Een dergelijke opvatting klinkt door in de woorden van Jonas Daniël Meijer, die in 1818 schreef:

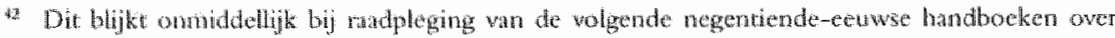

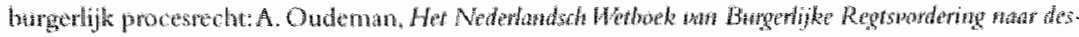

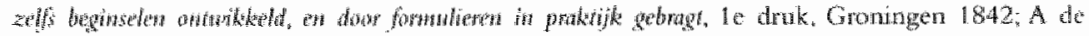

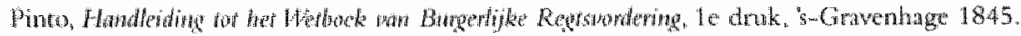

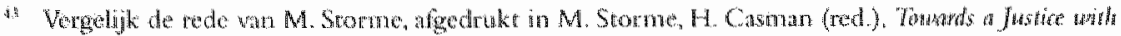

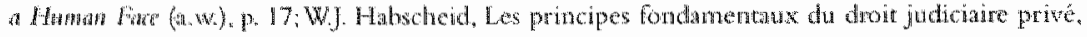

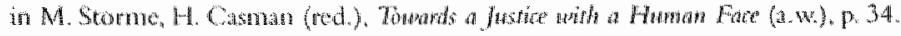


'[on] chercherait [...] vainement dans l'histoire l'exemple d'un peuple, qui sans avoir perdu son indépendence et son existence nationale, ait adopté la procédure d'une autre nation. ${ }^{44}$ Eenzelfde opvatting wordt aangetroffen in de Allgemeine Begrindung van de Duitse Zivilprozessorimung uit 1877, walar de overname van Frans procestecht in Duitsland niet juist wordt geacht op grond van de volgende overweging: "Eine Nation, deren in bedevtenden Geschichtsepochen stärker hervorragendes Rechtsbewusstsein nicht bloss das materielle Recht, sondern auch das Rechtsverfahren umfasst, würde sich in einem fremden Verfahren nicht wiedererkennen. ${ }^{25}$ Anderen verbazen zich over de nationale verschillen die op procesrechtelijk terrein bestaan. Zo stelt de afgevaardligde Dotrenge op 7 februari 1828 tijdens de beraadslagingen over het Nederlandse Wetboek van Burgerlijke Rechtsvordering het volgende: "Entre deux ou plusieurs nations civilisées ce n'est point de la conformité, mais de la disparité de leurs lois de procédures, qu'il devrait y avoir lieu de s"étonner et de se plaindre. ${ }^{85}$ In het huidige tijdsgewricht zetten schrijwers als de Amerikaanse auteur L.M. Friedman wragtekens bij de nawwe band die tussen een systeem van procesrecht en zijn doelgroep zou bestaan. ${ }^{47}$

Deze en soortgelijke opvattingen over de aard van het procesrecht hebben belangrijke consequenties voor de vraag of dit vakgebied al dan niet als een internationale discipline kan worden opgevat. Binnen het kader van de Europese Unie is deze vraag urgent. Immers, indien het procesrecht inderdaad een zeer nauwe band vertoont met een bepald volk of een bepaalde natie, dan kan van harmonisering van dit deel van het recht geen sprake zijn. Voorallsnog lijkt de opvatting dat het procesrecht nauw verbonden is met volk of natie de heersende te zijn. De regel dat rechters de woor hen aanhangig gemaakte zaken slechts volgens hun nationale procedureregels mogen behandelen, kan mogelijk mede als een uiting hiervan worden gezien. Deze beperking geldt niet op het wlak wan het materiële recht, waar het heel wel kan voorkomen, dat op een bepaalde rechtsverhouding buitenlands recht wordt toegepast.

In het licht van de heersende mening lijken de vooruitzichten wat betreft harmonisering van procesrecht in de Europese Unie somber. Indien de heersende mening juist is, kan worden gesteld, dat vormgeving van gehat--

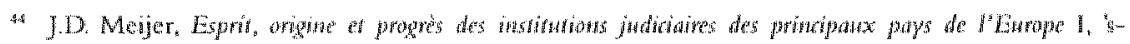
Grawentage 1818, p. XXX1.

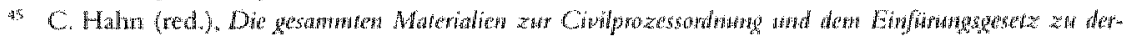

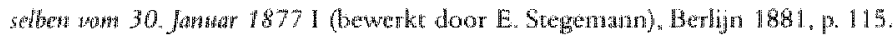

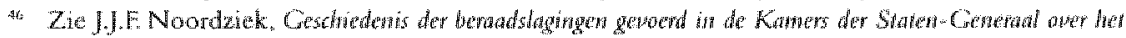

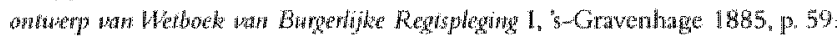

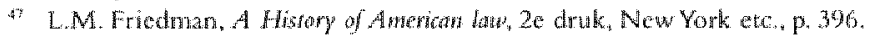


monisetrde procesrechtelijke regels die voor alle lidstaten van de Unie aanvaardbaat zijn wethaast als een onmogelijkheid moet worden beschouwd. Dit lijkt te worden bevestigd door het feit dat Europese harmoniseringsmatregelen van procesrechitelijke aard tot op heden schaars zijn gebleven. Het belangrijkste wapenfeit op dit gebied is het meermalen gewijzigde Verdrag betreffende de rechterlijke bevoegdheid en de tenuitvoerlegging van beslissingen in burgerlijke en handelszaken uit 1968. Hernieuwde pogingen om te komen tot een Europese aanpak van het procesrecht zijn weinig succesvol. Ik denk hierbij in de eerste plaats aan het rapport van de Working Growp on Civil Pyocedure in Europe getiteld Approximation of Judiciary Law in the European Union. ${ }^{46}$ Dit rapport, dat onder leiding van de Gentse emeritus M. Storme wan het begin van de jaren negentig werd opgesteld en dat vervolgens werd aangeboden aan de Europese Commissie, bevat harmoniseringsvoorstellen op deelgebieden van het procesrecht. Vooralsnog lijkt het rapport een anoniem bestaan in een Brusselse bureaulade te leiden.

Het gevolg van het ontbreken van geharmoniseerde regels van burgerlijk procesrecht in Europees verband is, dat op dit vlak obstakels blijven bestaan voor het soepel functioneren van de Europese interne rnarkt, met zijn vrij verkeer van personen, goederen, diensten en kapitaal. ${ }^{49}$ In dit kader is het belangrijk te bezien of de heersende mening omtrent de aard van het procestecht juist is. Is dit deel wan het recht inderdaad zodanig nauw verbonden miet de gemeenschap warvoor het is bedoeld, dat het weinig zin heeft om op dit vlak harmoniseringspogingen te ondernemen?

De geschiedenis van het procesrecht in West-Europa lijkt aan te geven, dat de juistheid van deze stelling valt te betwijfelen. Sterker nog, de onderlinge verwantschap die de verschillende West-Europese stelsels van procesrecht vertonen, vormt een uitgelezen basis op grond warvan een voor alle lidstatern wan de Europese Unie aanvaardbare, geharmoniseerde procedure kan worden vormgegeven. De wetenschappelijke bestudering van de historische verbanden tussen de onderscheiden procesrechten van de lidstaten is echter nog slechts in beperkte mate van de grond gekomen. Degenen die voorstellen doen om te komen tot harmonisering van het procesrecht in Europa, lijken

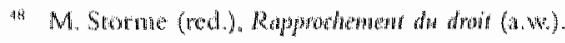

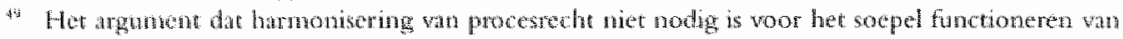

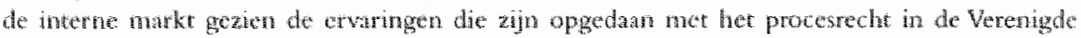

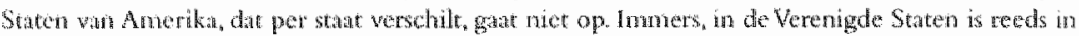

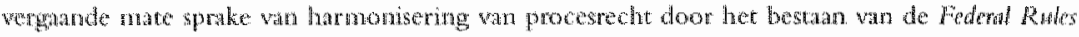

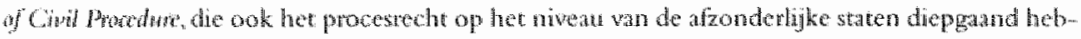
beir bermotod. 
zich onvoldoende bewust te zijn van de rol die de procesrechtsgeschiedenis in dit opzicht kan vervullen. Zo wordt in het rapport van Storme c.s. aan dit onderwerp nauwelijks aandacht besteed.

Waarom ben ik nu wan mening dat het procesrecht een minder nauw verband met zijn doelgroep vertoont dan wel wordt beweerd? In de eerste plaats kan worden gewezen op het succes van de Romano-canonieke procedure, die als een waar Ins Commune binnen het netwerk van kerkelijke rechtbanken in Europa functioneerde. Ondanks belangrijke verschillen tussen de volkeren waarover deze rechtbanken jurisdictie hadden, bleck het mogelijk om hun geschillen volgens een in grote lijnen eenvormige procedure af te handelen. Zoals wij hierboven zagen, bleek deze procedure zo succesvol te zijn, dat zij ook de manier van procederen van de wereldlijke jurisdicties in belangrijke mate is gaan beïnvloeden.

De invloed van het Romano-canonieke procesrecht op de seculiere procedure leidde, zoals gezegd, niet tot het ontstaan van een eenvormig procesrecht bij niet-kerkelijke jurisdicties. Er bestond een grote variëteit aan procesrechtelijke stijlen. Het bestaan van deze stijlen zou de aanleiding kunnen zijn woor het vermoeden dat bij wereldlijke rechtbanken wel sprake is wan procesrechtelijke regels die nauwe samenhang vertonen met kenmerken van de gemeenschap waarvoor zij bedoeld zijn. Bij nader inzien geloof ik echter niet, dat dit het geval is. Een eerste aanwijzing hierwoor is, dat zelfs bij rechterlijke instanties die functioneerden binnen eenzelfde gemeenschap belingrijke stijlverschillen zijn vast te stellen. Treffend is in dit opzicht het voorbeeld van het Hof van Holland en de Hoge Raad van Holland, Zeeland en WestFriesland gedurende het ancien régime. Ondanks de (bijna) identieke groep personen die aan de jurisdictie van deze hoven was onderworpen, vertoont het procesrecht van deze instanties belangrijke onderlinge afwijkingen. De oorzaak van deze verschillen wordt gevonden in de onderscheiden procesrechtelijke tradities warin het Hof van Holland en de Hoge Raad stonden. Het procesrecht van het Hof wan Holland werd namelijk in belangrijke mate beïnvloed door de stijl van de Raad van Brabant, ${ }^{50}$ terwijl de Hoge Raad zijn procesrecht ontleende aan de Grote Raad van Mechelen. ${ }^{5 t}$ De kenmerken

s) M. Oosterbosch, D. van den Auweele (red.), De ordonwantio wa 20 jum 1474 wor wo Rad wan Brabat, Brusse: 1993, p. XXIII.

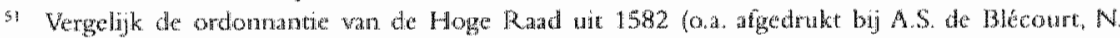

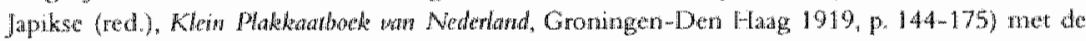
ordomantie van de Grote Rad van Mechelen uit 1559 (afgedrukt bij J. Bolsec (red)

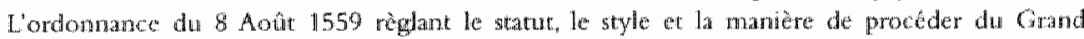

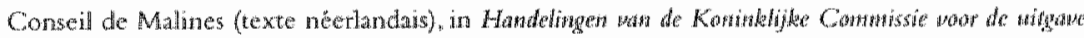

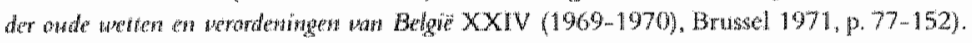


wan de binnen het territoir vain deze hoven levende groep personen, lijken een minder grote rol te hebben gespeeld.

De gedachte dat proces en gemeenschap onlosmakelijk met elkaar verbonden zijn, is ook niet te rijmen met gevallen waarin bepaalde landstreken of naties vreemd procesrecht recipieerden. Desalniettemin ontbreekt het niet aan voorbeelden hervan. Een treffend voorbeeld wordt in onze streken gevonden. In de vijftiende eeuw kan hier namelijk een toenemende invloed van het Frans-Bourgondische procesrecht worden waargenomen. Dit procesreche wortelt sterk in de procedure van het Franse Parlement de Paris, ${ }^{52}$ en is in belangrijke mate beinwoed door het Romano-canonieke procesrecht..$^{53}$ De schatplichtigheid aan de Frans-Bourgondische procedure blijkt ook op terminologisch vlak. Een ieder die Wielants Practije Civile of een willekeurige procesrechtelijke ordonnantie uit de Nederlanden ter hand heeft genomen, zal dit kuninen beamen.

In de zestiende eeuw bleven belangrijke procesrechtelijke impulsen uit Frankrijk komen. Zo werd destijds de Franse ordonnantie van Villers-Cotterets tot uitgangspunt genomen bij pogingen de procedure in de Nederlanden te stroomlijnen. ${ }^{54}$ Daarbij kwam het weleens voor dat een bepaalde regeling niet passend werd bevonden voor de Lage Landen, maar die gevallen zijn vrij zeldzaam. Het procesrecht dat aldus in de zestiende en daaraan voorafgaande eeuwen hier te lande werd vormgegeven, heeft in de latere Republiek geen belangrijke wijzigingen ondergaan.

Ook in de meer recente geschiedenis zijn geslaagde gevallen van export van procesrecht beeldbepalend voor het Europese juridische landschap. In dit kader is de Napoleontische periode van blijvende betekenis. Niet zozeer omdat de Napoleontische codificaties met wapengekletter in verschillende Europese landen konden worden geintroduceerd, mar veeleer omdat deze codificaties na de nederlaag van de Franse keizer in veel landen een vruchtbate toekomst tegemoet gingen. Dit gold a fortiori voor de Code de proddure divile, die op vele plekken de eigen procedure van de onderworpen naties had vervangen. Indien procesrecht nu werkelijk niet kan worden losgedacht wan de gemeenschap warwoor het is bedoeld, zou men verwachten dat procesrechtelijke regelingen van de overheerser na herstel van de onathankelijkheid zo snel mogelijk zouden worden afgeschaft. Eigen procesrecht zou hiervoor in de platats dienen te worden gesteld. De geschiedenis nam echter een

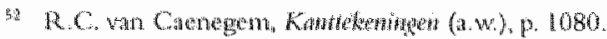

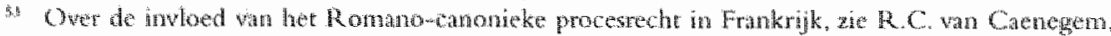

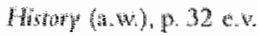

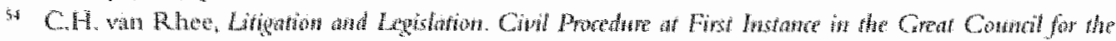

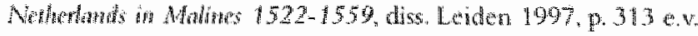


andere loop. Opvallend is dat de Code de prodedure civile in veel landen hetaij werd gelhandhaafd, hetzij het karakter bepaalde van nieuwe regelingen wan eigen bodem. Belgie is in dit opzicht een veelzeggend voorbeeld. Daar werd de Code de procédure civile pas in de tweede helft van de twintigste eeuw vervangen door het Gerechtelijk Wetboek van 1967.5. Dit mag opmerkelijk worden genoemd, aangezien de jonge staat België in de negentiende eeuw verwoede pogingen deed een eigen, nationale identiteit op te bouwen. Hierbij vormde de geschiedwetenschap een belangrijk instrument, zozeer zelfs, dat men niet voor geschiedvervalsing en anachronismen terugdeinsde ${ }^{5 / 6}$ Indien nu inderdaad procesrecht en wolk nauwe verwantschap vertonen, zou men verwachten dat in België het Franse wetboek zo snel mogelijk door een product van eigen bodem zou zijn vervangen. Dit gebeurde echter niet. Blijkbaar viel het dus met het uitgesproken nationale karakter van het procesrecht nogal mee.

Ook in Nederland was de Franse invloed blijvend. Hoewel hier reeds in 1838 een nationale procesrechtelijke codificatie werd ingevoerd (in Limburg gebeurde dit iets later), vormde deze codificatie in belangrijke mate een kopie van de Franse Code de procedure civile. Opvallend is dat afwijkingen van het Franse voorbeeld meestal niet het gewolg waren wan de omstandigheid dat eigen, nationaal procesrecht in het wetboek werd opgenomen. Dit gebeurde slechts in een gering aantal gevallen, bijvoorbeeld wat betreft de eis in reconventie, het voorlopig getuigenverhoor en de procedure in revisie (procesrechtelijke figuren die overigens hun wortels vinden in het FransBourgondische procesrecht uit de vijftiende en zestiende eeuw). In de meeste gevallen waren dexe afwijkingen een consequentie van de onstandigheid dat procesrecht uit een andere buitenlandse bron, namelijk het wetboek van Genève, tot voorbeeld werd genomen ${ }^{57} \mathrm{Op}$ deze wijze werd een procedure vormgegeven die wat betreft herkomst het stempel 'nationalal' niet kan dragen.

Tot dusver heb ik mij geconcentreerd op het procesrecht van de landen op het Europese continent. Voor deze landen hoop ik te hebben angetoond, dat het verband tussen de procedure en de specifieke kenmerken van het binnen de grenzen wan deze landen levende wolk minder evident is dan wel wordt verkondigd. Daarmee lijken, wat betreft het Europese continent, harmonise-

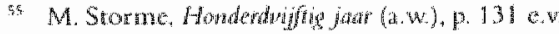

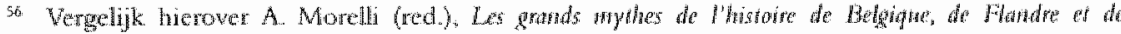

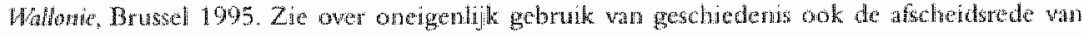

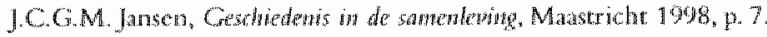

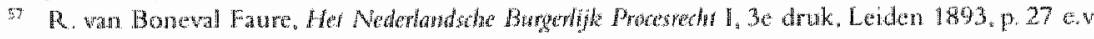


ringsimatregelen op procesrechtelik terrein niet bij voorbat tot mislukken gedoend. Kest mij de Britse elanden in mijn beschouwingen te betrekken. Ik zal mij hierbij concentreren op het procesrecht van Engeland en Wales, dat ik kortweg als het Engelse procesrecht zal anduiden.

Het Engelse procestecht wijkt in belangrijke mate af wan zijn tegenhanger op het Europese continent. Zo kent de Engelse procedure een onderscheid tussen een pretrial en en trialfase. De pretrialfase is onder andere bedoeld voor thet wisseleri van pleadings (conclusies). Indien partijen de zaak niet voritidig wensen te beéindigen, wordt de zaak gedurende deze fase zodanig worbereid, dat en efficiẻnte mondelinge behandeling voor de rechter kan platsvinden gedurende trial. Deze tweedeing van het proces kan mede in verband worden gebracht met het gegeven dat men in Engeland tot in deze eeuw ook in burgerljke zaken juryrechtsprak kende. Trial was het moment warop de jury wan de zaak kennisnam en op dat monnent moest de zaak met voldoende duidelijkheid worden gepresenteerd, hetgeen alleen mogelijk was na een grondige woorbereiding tijdens de pretrialfase.

De Engrelse juryrechtspraak en de daarmee samenhangende inrichting van het proces kumnen worden beschouwd als het resultat van typisch Engelse opvatingen over de inrichting wan de matschappij. Juryrechtspraak geefit uitdrukking aan de gedachte dat leken invloed op de rechtsbedeling dienen te hebben. Echter ${ }^{2}$ hoewel het procesrecht in Engeland dus een duidelijk national karakter heeft, is de samenhang tussen thet Engelse volk en zijn procedure niet zodlanig groot, dat het procesrecht zich kan ontrekken aan beinwoeding van buttenaf. Import van procesrechtelijke regels windt ook in Engeland plaats. Hiervan was reeds sprake in de Middeleeuwen.

Zoals bekend, wordt in Engeland een onderscheid gemakt tussen twee stelsels van rechtsregels en rechtsprincipes. Enerzijds is er het stelsel van Common Law (kortweg Law) en anderzijds het stelsel dat wordt aangeduid als Equi$\gamma$. Equiry ontstond als correctief op Common Law, dat doorheen de tijd een weinig buigzam geheel wan rechtsregels was gan vormen. ${ }^{60}$ Equtyrecht-

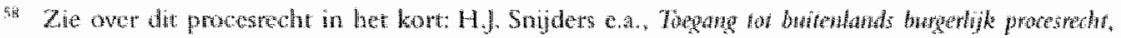

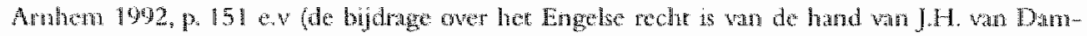

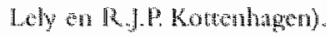

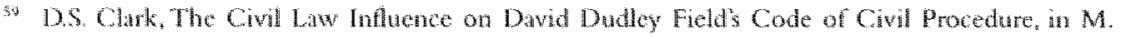

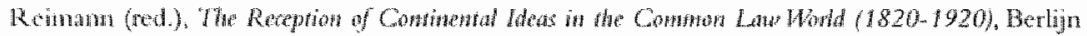
$199,7.76$

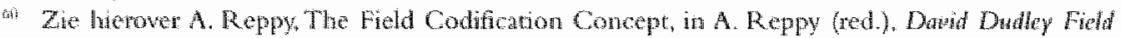

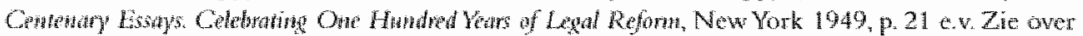

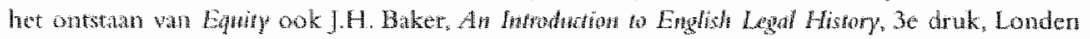

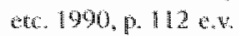


spraak werd verzorgd door de kanselier van de Engelse koning in het Court of Chancery, waar een eigen procesrecht tot ontwikkeling kwam. Dit procesrecht vertoont sporen van de Romano-canonieke procedure, hetgeen samenhangt met het feit dat de Engelse kanselier oorspronkellijk wend gekozen uit de rangen van geestelijken. Daardoor bezat hij kennis van het $\mathbb{R}$ omano-canonieke procesrecht. ${ }^{6 !}$

De equityprocedure bleef tot in de negentiende eeuw bestaan nast het procesrecht van Common Law. In 1873-1875 werd een nieuw, eenwormig procesrecht ingevoerd als ondendeel van de zogenoemde Judicature Acts. Dit nieuwe procesrecht bevatte elementen uit zowel de oude Common Law-procedure als de equityprocedure. Bovendien werden belangrijke procestechtelijke regels ontleend an de op Romano-canonieke leest geschoeide procedure van het Admiralty Court. ${ }^{62}$ Nader onderzoek zal moeten aantonen in hoeverre het huidige Engelse procesrecht Romano-canonicke elementen bevat uit de eqmityprocedure en uit de procedure van het Admiralty Court. De kans dat Romano-canoniek gedachtegoed in de Engelse procedure kan worden. aangewezen, is groot, mede omdat het niet uitgesloten moet worden geacht dat Amerikaans procesrecht, in thet bijzonder de Field Code van New York, invloed op het Engelse procesrecht uitoefende. ${ }^{63}$ De Field Code introduceerde reeds in 1848 een eenvormige burgerlijke procedure in New York. Bij het vormgeven hiervan speelde het procesrecht van de staat Louisiana een rol van betekenis. ${ }^{64}$ Het procesrecht van Louisiana moet in de procesrechtelijke traditie van het continent van West-Europa worden gesitueerd. Dientengevolge heeft dit procesrecht een $\mathbb{R}$ omano-canoniek uiterlijk. Het is niet uitgesloten dat Romano-canonieke elementen in de Engelse procedure terecht zijn gekomen via de door Louisiana beïnloede Field Code.

Wanneer kan worden aangetoond dat export van buitenlandse procesrechtelijke regels naar Engeland heeft plaatsgevonden en tevens dat deze export van enige betekenis is geweest, leidt dit tot de conclusie dat zelfs de Engelse procedure in mindere mate een national verschijnsel is dant well wordt gesteld. Zo dit het geval is, behoeft de kans dat Europese harmonise-w ringsmaatregelen stuklopen op het typisch Engelse karakter van het Engelse procesrecht niet onoverkomelijk groot te zijn. De kans dat harmoniserings-

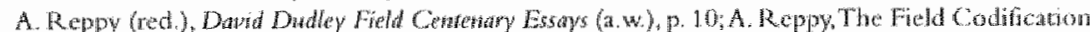
Concepr (a.w., p. 48, C.E. Clark, Code Pleading and Practice Today in A. Reppy (red), Dovid

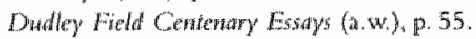

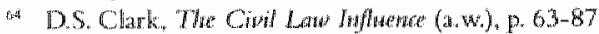


matregelen slagen, wordt overigens nog vergroot door de onstandigheid dat het Engelse en het continentale procesrecht de latste deceninia enigsins naar elkat toe lijken te groeien. Gewezen kan bijvoorbeeld worden op de Engelse Mareva Injunction, die op bepaalde punten gelijkenis vertoont met het conservatoire beslag van bet continentale Europese recht. ${ }^{65}$ Omgekeerde beinvloeding vindt overigens ook plaats. Men denke aan de Anglo-Amerikanise discoveryprocedure, die zich op dit moment in grote belangstelling op het $\mathbb{E u -}$ ropese continent kan verheugen. ${ }^{6}$ Discovery stell een partij in staat haar wederpartij te dwingen relevante informatie over de zaak te verstrekken.

Ter afsluting van dit onderdeel dient te worden opgemerkt, dat ik mij hier vooral heb beziggehouden met de vraag of eenvormige procesrechtelijke regels kunnen worden vormgegeven. Eenvormige regels zijn natuurlijk geen garantie voor een eenvormige interpretatie en toepassing van deze regels in de praktijk. Voor de praktijk geldt de stelling van R. Stïrner, luidende: 'Dass Mentalitátsunterschiede und Lebensgewohnheiten die Praxis der Rechtsdurchsetzung mitprägen und zu Unterschieden führen mögen, ist eine alltägliche Weisheit. ${ }^{67}$ Deze stelling heb ik in het voorgaande geenszins proberen te ontkrachten. Niettemin is het mijns inziens belangrijk te bestuderen of in Europees verband mogelijkheden bestaan om te komen tot een eenvormige procesrechtelijke regelgeving. Een dergelijke regelgeving zal immers de kans vergroten, dat ook in de praktijk de procedures van de verschillende Europese landen meer en meer op ellkar gaan ljken. ${ }^{\circ}$ Hiertoe zal de mogelijkheid c.q. de plicht prejudiciele vragen te stellen aan het Hof van Justitie van de Europese Gemeenschappen het hare kumen bijdragen.

\section{PROCGSRECHTSGESCHEDENIS EN EEN EFFICIENTE PROCESGANG}

Ik kom toe aan behandeling van de tweede vraag die ik in de inleiding stelde, namelijk welke rol de geschiedenis van het procestecht en de rechtsvergelijking kunnen spelen bij het vormgeven van toekomstig burgerlijk procesrecht.

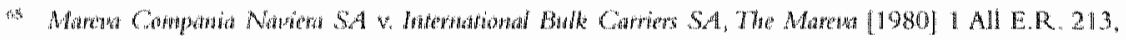

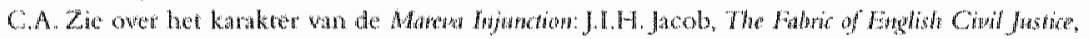
Londen $1987, p .136$ e.

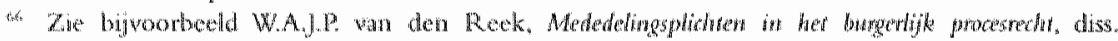

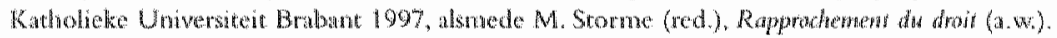

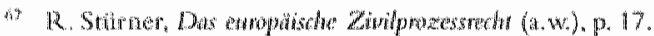

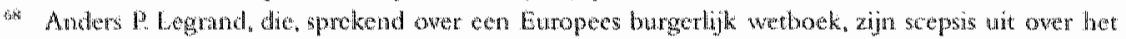

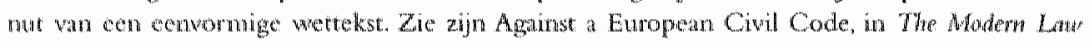
Kevew $60(1997), 0.60$. 
Aan het begin van mijn rede omschneef ik het procesrecht (in engere zin) als een samenhangend geheel wan formaliteiten die juridische procedures van de aanvang tot het einde reguleren. In burgerlijke zaken wordt met dit procesrecht eerst en vooral vaststelling, effectuering dan wel vormgeving van privaatrechtelijke rechten en plichten, en daarmee het beëindigen van situaties waarin onrecht heerst, nagestreefd ${ }^{69}$ Aan de formaliteiten die men bij dit streven in acht neemt, wordt een antal eisen gesteld. $Z$ ij dienen de rechtsstrijd op zodanige wijze te reguleren, dat de kans op onjuiste, dat wil zeggen onrechtvaardige beslissingen wordt geminimaliseerd. De kans op een onrechtvaardige beslissing is groot indien de rechter uitgaat van onjuiste gegevens. Dientengevolge is een aanzienlijk aantal procesrechtelijke formaliteiten gericht op het scheppen van optimale voorwarden voor watheidsvinding. Maar hierbij blijft het niet, aangezien de aard van de rechten en plichten die in het burgerlijk proces centraal staan, verdere eisen aan de procesrechtelijke formaliteiten stelt. Immers, het gat hicr om privalatrechtelijke rechten en plichten, en de vraag of deze rechten en plichten dienen te worden vastgesteld, geëffectueerd dan wel vormgegeven, wordt traditioneel beschouwd als een particuliere aangelegenheid. Dit brengt met zich dat aan partijen de vrijheid moet worden gelaten te beslissen of zij al dan niet een procedure atanhangig willen maken en tevens op welke wijze zij hun proces wensen te voeren. De rechter dient dus partijen zijn beslissing niet op te dringen, maar slechts werkzaam te zijn op hun verzoek. Ten slotte dienen de gestelde formaliteiten geen aanleiding te geven tot een trage en kostbare procesgang. Een trage en kostbare procesgang betekent, dat situaties waarin onrecht heerst, kunnen worden gecontinueerd, terwijl het procestecht nu juist gericht is op de beëindiging van dergelijke situaties. ${ }^{70}$

De verschillende eisen waaraan het procesrecht moet voldoen, leiden tot het ontstaan van een spanningsveld. Enerzijds dienen procesrechtelijke regels een goedkope en snelle procedure te garanderen, mat anderzijds behoren optimale voorwaarden voor waarheidsvinding te worden gecreèerd en dienen partijen in staat te worden gesteld invloed op de loop van het proces urt te oefenen. De latatste twee eisen kunnen het proces ernstig vertragen en de

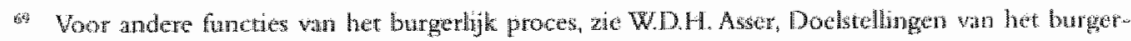

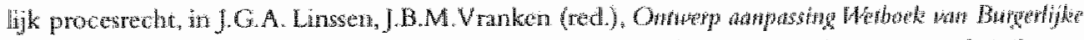

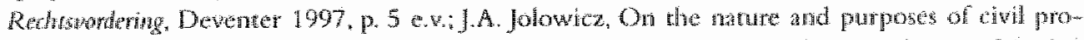

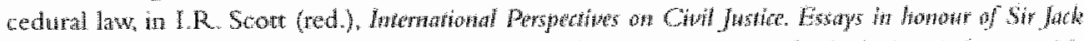

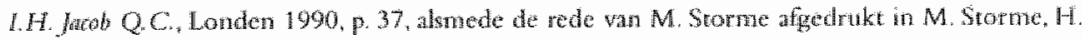

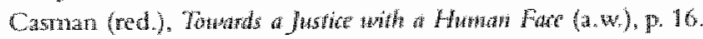

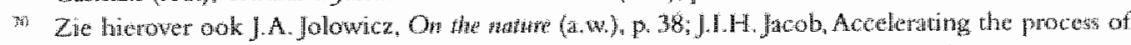

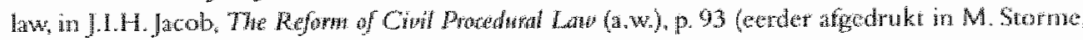

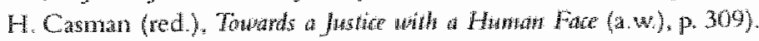


aanleiding zijn voor aanzienlijke kosten. Immers, in de eerste plaats is een grondig onderzoek naar de warheid meestentijds niet binnen een korte periode en met min kostbare middelen te realiseren. Zo wordt een optimale watrheidsvinding bevorderd doot een procedure die partijen toelaat hun standpunt zo uitvoerig mogelijk uiteen te zetten, alsmede het standpunt van hun wederpartij zo uitvoerig mogelijk te becommentariëren. Ten tweede brengt het feit dat dan partijen de mogelijkheid moet worden gellaten de loop van het proces te beirmvloeden met zich, dat zij het proces niet alleen kunnen vertragen, maar dat zij het ook kunnen maken tot een kostbare aangelegenheid.

Het hierboven gesignaleerde spanningsveld maakt, dat het zeer moeilijk is een bevredigende procedure vorm te geven. Ontevredenheid met het bestande recht en hervormingspogingen zijn dan ook kenmerkend voor de geschiedenis van het procesrecht. De klachten betreffen onveranderlijk de tragheid van het proces, zijn grote complexiteit en zijn hoge kosten. ${ }^{71}$ Zelfs in niet-juridische bronnen wordt deze problematiek besproken. Gewezen kan bijvoorbeeld worden op Pantagruel van François Rabelais, ${ }^{72}$ Hamlet van William Shakespeare, ${ }^{73}$ Gulliver's Travels van Jonathan Swift ${ }^{74}$ en Bleak House van Charles Dickens.

De klachten die in het verleden over het procesrecht werden geformuleerd, bestaan ook heden nog. Dit geldt zowell voor Engeland als voor de landen op het Europese continent. Recentelijk heeft Lord Woolf de procedure in Engeland en Wales als durur en kostbaar gebrandmerkt. ${ }^{75}$ Ook in Nederland streeft de wetgever tot op de dag van vandaag naar stroomlijning van het

7 Zie bijvoorbece M. Zander, Why Land Woalfs Proposed Reforms of Civil Licigation should be

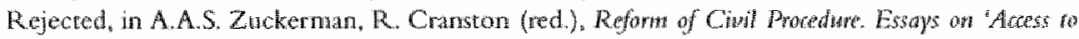

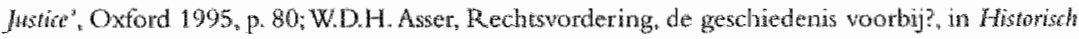

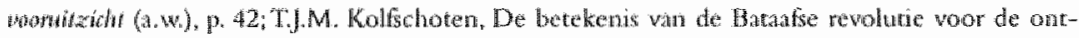

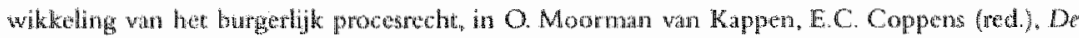

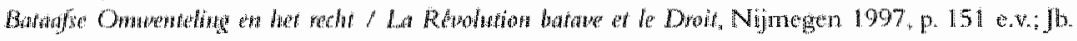

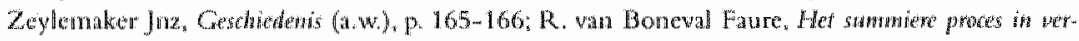

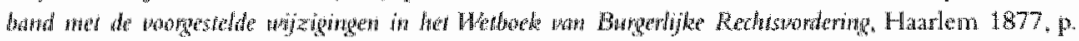
15 .

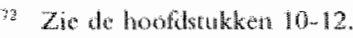

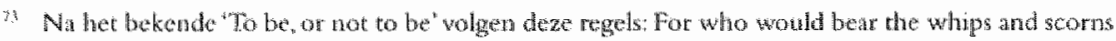

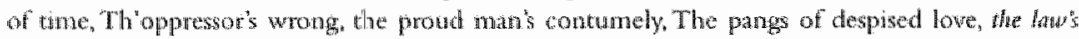

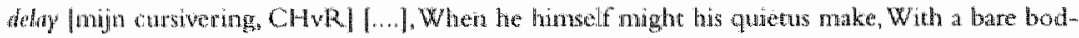
kin?

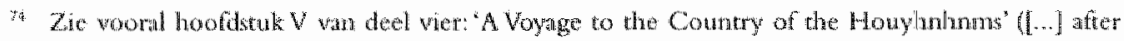
which they consult precedents, adjoura the cause from tine to time, and in ten, twanty or thry years come tor atis issues.

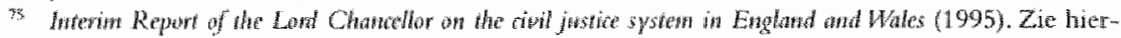
Mor A.A.S. Zuckerman, Retorm in the Shadow of Lawyers" Interest, in A.A.S. Zuckerman, R. Cranston (red.), Refom (a.w) , B. 61 . 
procesrecht, getuige onder meer het recente wetsontwerp 24651 tot herziening van de rechterlijke organisatie en het Wetboek van Burgerijke Rechtsvordering (dat overigens onlangs is ingetrokken, maar warvan de inhoud ten dele in een nieuw wetsontwerp zal worden neergelegd). ${ }^{76}$ Door sommigen wordt gesteld dat klachten over de procedure deels kunnen worden herleid tot de ouderdom van de wettelijke regels op dit gebied. Zo stelt J.M. van Veggel: 'Daarnaast dient niet vergeten te worden dat ons Wetboek van Burgerlijke Rechtsvordering al meer dan honderdvijftig jaren bestaat. Procedures die men toen als vlot behandeld zag, worden nu als traag gezien. ${ }^{77}$ Het is echter maar de vraag of deze stelling in haar algemeenheid juist is. Natuurlijk is het mogelijk dat men tegenwoordig in bepaalde zaken hogere eisen stelt aan de snelheid warmee een geschil tot een oplossing komt dan in het verleden. Echter, in het merendeel van de gevallen lijken de huidige eisen die men aan de voortgang van het proces stelt als twee druppels water op die uit het verleden. Bij de zestiende-eeuwse Grote Raad duturde een gemiddelde eerste-aanleg zaak zo"n twee tot drie jaar ${ }^{78}$ en desalniettemin vond men het noodzakelijk de procedure te hervormen. ${ }^{79}$ In Nederland is momenteel sprake van een vergelijkbare situatie ${ }^{80}$ en ook nu streeft men naar versnelling.

In het licht van het bovenstaande zou men verwachten, dat grote belangstelling bestaat voor eerdere pogingen de procedure te stroomlijnen. Helaas moet worden geconstateerd dat dit niet het geval is, zeker niet bij degenen. die belast zijn met nieuwe hervormingspogingen. Veelal beperkt de aandacht van hervormers zich tot het hier en nu. Lord Woolf noemt bijvoorbeeld slechts de twee meest recente rapporten van de ongeveer zestig rapporten die in Engeland sinds het midden van de negentiende eeuw zijn uitgebracht betreffende aspecten wan het procesrecht en de organisatie van de gerechten. ${ }^{81}$ Ook in de memorie van toelichting op het hierboven genoemde Nederlandse wetswoorstel wordt geen aandacht geschonken aan het verleden. Het resultat hiervan is onder andere een passage in deze memorie waar wordt opgemerkt, dat "[t]egenwoordig [mijn cursivering, CHvR] [...] bók civiele procedures op de eerste plaats vlot [dienen] te verlopen, willen zij aan de

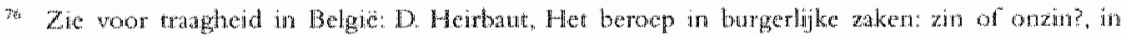

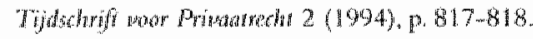

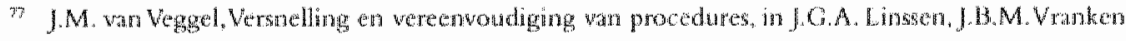

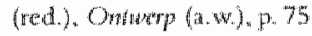

7. C.W. wa Rhee, Lituation (a.w.). P. 342

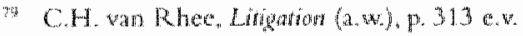

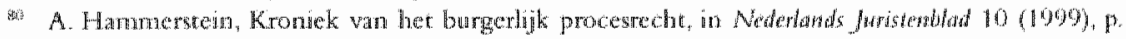
458

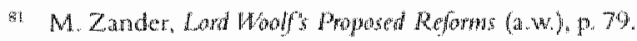


de matschappelijke eisen van de tijd en aan de eisen wan een goede rechtsprak voldoen. ${ }^{\text {sk: }}$ Het woord 'tegenwoordig' had hier beter achterwege kunnen blijven. Inmers, de geschiedenis van het procesrecht toont aan dat men reeds sinds mensenthengenis van mening is dat civiele procedures vlot dienen te verlopen. Een bewijs laiervoor in de meer recente geschiedenis kan worden gevonden in de Handelingen van de Nederlandse Juristenverenging uit 1881. JJ. van Geuns stelt daar het wolgende: "Geheel onze tijd streeft naar snelheid; de verbeterde middelen van gemeenschap, het toegenomen handelsverkeer, uitvindingen op elk gebied, meer algemeen gemaakte kemnis en daardoor ook meer inspanning, die van den burger gevorderd wordt, zouden eischen, dat de vraag, wat in vele levensbetrekkingen recht is, doorgaans ook des te spoediger kon worden opgelost; maar het samenstel van vormen en formaliteiten, dat op die wraag antwoord moet geven, blijft denzelfde, op geringe uitzonderingen na, onverstoord tragen gang gaan. ${ }^{3,3}$

Ik kan vandaag niet alle punten uit de procesrechtsgeschiedenis behandelen die bij het vormgeven van efficiënt hedendaags burgerlijk procesrecht nadere bestudering vereisen. I $\mathrm{kal}$ mij dan ook beperken tot een van deze punten, namelijk de pogingen een snelle en goedkope procedure vorm te geven door te kiezen voor versterking van het mondelinge element in de procesgang.

Door velen wordt een mondelinge procedure, althans een procedure waarin naast het geschrift ruime plats is ingeruimd voor het gesproken woord, gezien als de oplossing voor traagheid en hoge kosten. ${ }^{8-4}$ Men stelt dat een mondelinge procedure de mogelijkheid biedt geschilpunten snel te omlijnen en de waarheid spoedig op tafel te krijgen zonder dat al te grote concessies behoeven te worden gedaan op het gebied van de partijautonomie. Een procedure waarin de nadruk wordt gelegd op geschriften, acht men daarentegen nadelig te zijn voor een efficiënte procesgang. ${ }^{\sharp 5}$ De aanhangers van deze opvatting zullen het dan ook van harte eens zijn met de aanpak van Pantagruel, toen deze stelde: [...] si voulez que je connaisse de ce procès, premièrement faites-moi brûler tous ces papiers; et secondement, faites-moi venir les deux gentils hommes personnellement devant moi, et quand je les

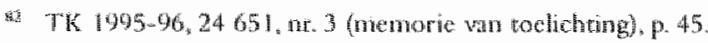

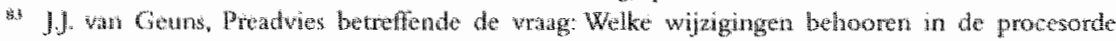

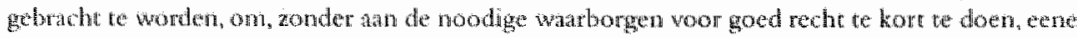

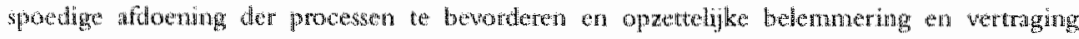

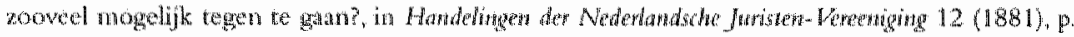
274

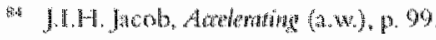

a. Binger, De denkbedden van Mr. EJ.A. Fles over bet onal debat in horgerlige zaken in

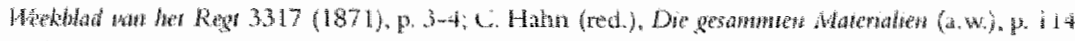
an 117 
aurai oüs, je vous en dirai mon opinion sans fiction ni dissimulation quelconque. Echter, dat een mondelinge procedure niet zonder meeir een oplossing is voor de gesignaleerde problematiek, bewijst rechtsvergelijkend en rechtshistorisch onderzoek.

In de eerste plats kan worden gewezen op het Engelse procesrecht, wolgens hetwelk zaken in belangrijke mate mondeling worden afgedaan ${ }^{87}$ Desalniettemin is de Engelse procedure niet het toonbeeld van efficiency ${ }^{\text {ss }}$ H. Kötz kenschetst de procedure van het Common Lan' als de 'Rolls Royce of civil procedures. ${ }^{964}$ Dit lijkt een juiste kenschets, aangezien deze procedure enerzijds kwalitatief van zeer hoge aard is (er wordt bijwoorbeeld in wergaande mate recht gedaan aan het beginsel van hoor en wederhoor en er vindt een zeer degelijk feitenonderzoek plaats), maar anderzajds blijkt zij zo traag en kostbaar te zijn, dat velen zich enige malen zullen bedenken alvorens zij hun recht via de Engelse rechter trachten geldend te maken.

Ook de rechtsgeschiedenis bewijst dat een mondelinge procedure niet de panacee is voor snellheid en lage kosten. De Romano-canonieke procedure legde, zoals bekend, de nadruk op het geschrift. Voor dit procesrecht gold de regel 'quod non est in actis, non est in mundo', ofwel, de rechter baseert zijn oordeel louter op hetgeen schriftelijk is vastgelegd. De inheemse procedure daarentegen, waarvan vele elementen door het geleerde proces langzaam zouden worden verdrongen, was mondeling van aard. Desalniettemin stelt $L$. Fowler-Magerl vast, dat de receptie van het Romano-canonieke procesrecht: gunstig werd beinvloed door de omstandigheid dat de geleerde (schriftelijke) procedure sneller tot een eindoordeel leidde dan de inheemse (mondelinge) manier van procederen. ${ }^{90}$

In het licht van het bovenstaande, is nadere bestudering van procesvormen, waarin de nadruk wordt gelegd op mondelinge elementen, nuttig voor hervormers die zich thans met het procesrecht bezighouden. Hun bijzondere aandacht verdient de omstandigheid dat zulke mondelinge elementen in het verleden vaak werden ingevoerd met als doel het proces efficiënter te maken maar zich vervolgens niet lang wisten te handhaven.

Een interessant studje-object vormt in dit kader de zogenoende summiere procedure. De basistekst voor de summiere procedure is de bekende decretale Saepe van Paus Clemens V. ${ }^{91}$ Deze decretale bewerkstelligde in 1312-14

Weze passage komt voor in hoofdruk 10 wan Parng prel.

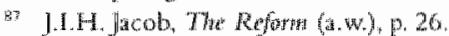

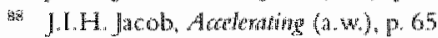

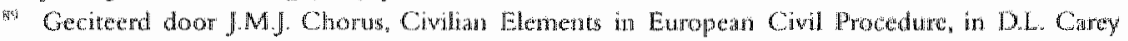

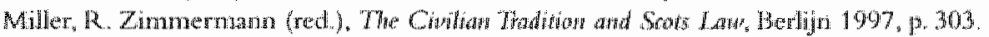

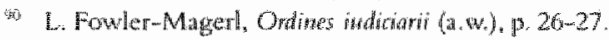

c. 2 CH. Vis. 11 . 
de officiele introductie in het Romano-canonieke procesrecht van een snelle procesgang voor een beperkt aantal gevallen. Volgens deze summiere procesgang werden zaken simpliciter, de plano, sine strepitu et figura indici afgedaan, dat will (vrij vertald) zeggen: eenvoudig, zonder omhaal en zonder het tumult en de vorm van een [gewone] procedure. Dit bracht met zich dat het proces in belangrijke mate mondeling van aard was. ${ }^{92}$ Hoewel nu het mondelinge element een belangrijke component was wan de oorspronkelijke summiere procedure, werdwijnt dit element zodra wordt getracht de summiere procedure alls standaardprocesvorm voor alle gevallen in te voeren. Een voorbeeld laiervan wormt de regelgeving van de Rijksdag in Regensburg uit $1654 .^{93}$ Deze regelgeving introduceerde bij thet Duitse Rijkskamergerecht een procedure die was gebaseerd op het in Saksen gebruikelijke summiere proces. ${ }^{94}$ De aldus vernieuwde procedure was in hoge mate schriftelijk van aard. Een ander woorbeeld is de Nederlandse Lex Hartogh uit 1896, die eveneens een op het summiere proces geinspireerde standaardprocedure invoerde. ${ }^{45}$ Ook hier is het mondelinge element naar de achtergrond gedrongen.

Een tweede interessant studie-object, waar eveneens een verdringing van mondelinge elementen ten gunste van een meer schriftelijke procesvoering kan worden watgenomen, is het Duitse procesrecht zoals dat door de Zivilprozessordriang van 1877 werd vormgegeven. Oorspronkelijk mocht volgens de Zivilprozessordnung slechts hetgeen mondeling werd voorgedragen aan de rechterlijke beslissing ten grondslag worden gelegd. ${ }^{96}$ Echter, reeds in 1924 werden maatregelen genomen waardoor het mogelijk werd onder omstandigheden van een mondelinge behandeling van de zaak af te zien. ${ }^{97}$ Hoewel G. Baumgärtel nog in de jaren zeventig van deze eeuw ijverde voor versterking van het mondelinge element in de Duitse procedure, ${ }^{98}$ is daarna een verdere uitbreiding van scliriftelijke elementen waar te nemen. ${ }^{99}$

Zie ook R. C. wh Caenegem, Hosiory (a.w), p. 20

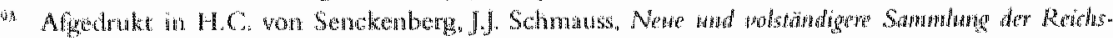

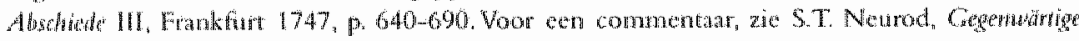

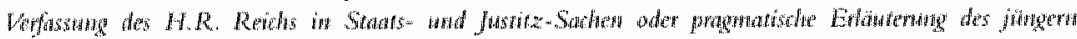
Reids-Aldschids, Jona 1752

w. R.C. van Cacingen, Horoy (a.w), p. 57.

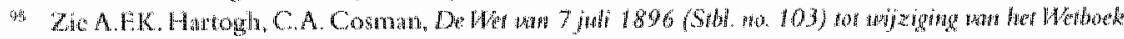

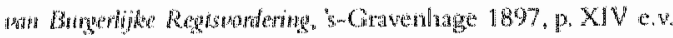

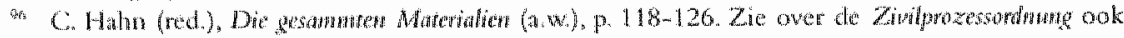

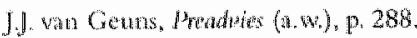

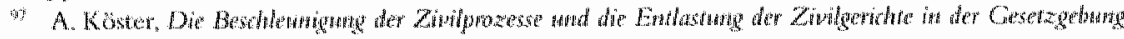
mos 1879 bis 1993 1, Frankfuet etc. 1995, p. 21.5 <.

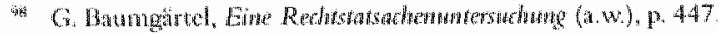

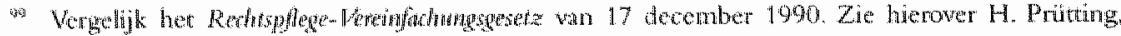

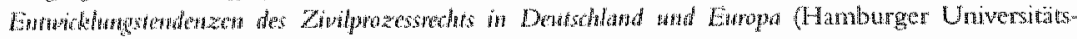
reders 5.47, Hanburge $1993, \mathrm{p} .27$. 
Ook andere landen kozen meer en meer voor een procesgang met de nadruk op het geschrift. Belgie deed dit bij invoering valn het Genechtelijk Wetboek in 1967. ${ }^{100}$ In Engeland is eveneens een beweging te zien in de richting wan een schriftelijke procedure, zij het dan slechts voor zaken wan gering belang (small daims). ${ }^{101}$ Gezien het blijvende vertrotwen in het mondelinge proces, clat thans tegelijkertijd in veel Europese landen ${ }^{102}$ kan worden geconstateerd (men denke bijwoorbeeld aan het versneld regime in Nederland, alsmede aan het rapport van de Commissie Leemhuis), dient onderzocht te worden waarom de pogingen die in het verleden zijn gedaan om een proces vorm te geven warin de nadruk op een mondelinge behandeling lag, zijn mislukt. Daarmee kan mogelijkerwijze de vragg worden beantwoord of het gesignaleerde vertrouwen in de mondelinge procedure gerechtvaardigd is, dan wel oplossingen voor een trage en dure procedure beter in een andere richting kunnen worden gezocht.

\section{BESLUIT}

Ik hoop $\mathrm{U}$ vandaag te hebben overtuigd van het feit dat procesrecht niet het uitsluitend domein behoeft te zijn van "geistlosen Praktikern. ${ }^{103}$ Vanaf de twaalfde eeuw is het procesrecht telkens weer als een wetenschappelijke discipline opgevat. Het heeft zich door de tijden heen kunnen verheugen in de belangstelling van juristen van formaat. Ook momenteel bestaat op procesrechtelijk terrein een veelheid van vragen die een wetenschappelijke, rechtshistorische en rechtswergelijkende aanpak vereisen. Enige van deze vragen heb ik vandaag onder uw aandacht gebracht. Het is mijn voornemen deze en dergelijke procesrechtelijke vragen in de komende jaren zowel in mijn. onderzoek als in mijn onderwijs centraal te stellen. Daarmee hoop ik een bijdrage te leveren aan pogingen het procesrecht in Europees verband te harmoniseren. Bovendien hoop ik met mijn onderwijs en onderzoek duidelijk te maken, dat de problemen waarmee wij heden ten dage op procesrechtelijk terrein worden geconfronteerd, niet louter iets zijn van het hier en nu. Deze problemen zijn zo oud als ons procesrecht zelf. Ditzelfde geld: voor pogingen on door hervorming van de procedure de gesignaleerde proble-

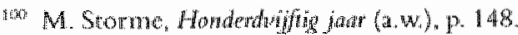

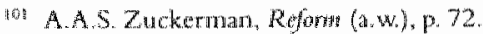

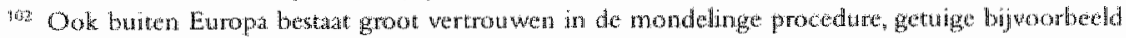

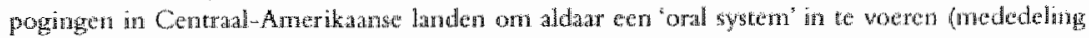
wan M.A. Field, Langdall Profeson of Law, Harnard Law School, de betrokkon is bij deze pogengetrol.

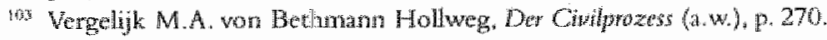


then het hoofd te bieden. Vroegere hervormingspogingen mogen door hedendatagse hervormers niet domweg geignoreerd worden. In het hwidige tijdsgewricht, met zijn minachring voor historische tradities en zijn voor toekomstige academici - althans voor hen die zich zullen bewegen op het terrein der humaniora - inadequate middelbare onderwijs in de geschiedenis, is het zaak steeds weer in gedachten te roepen, dat het heden en de toekomst slechts te doorgronden zijn met voldoende kennis van het verleden.

\section{MUNHEIR DE RECTOR MAGNIFICUS, ZEER GEACHTE AANWEZIGEN,}

Graag wil ik mijn dank uitspreken jegens degenen die in mij het vertrouwen hebben gesteld dat geleid heeft tot minn benoeming. lk denk hierbij in het bijzonder aan de leden wan het College van Bestuur en aan het bestuur van de Faculteit der Rechtsgeleerdheid. I $\mathrm{k}$ voel mij in Maastricht thuis, hetgeen mede een gevolg is van de welwillendheid waarmee de collega's van de juridische faculteit mij in hun midden hebben opgenomen.

Beste Tanja en Louis. Het is nu bijna een jaar geleden dat ik werd toegevoegd aan het driespan dat jullie tot dan samen met Ton Gehlen vormden. Ik geloof dat wij steeds meer aan elkaar beginnen te wennen. Ik verheug mij erop de komende jaren het Maastrichtse rechtshistorisch onderwijs en onderzoek samen met jullie in goede harmonie vorm te gever.

Waarde Wijffels, beste Alain. Vanaf het moment waarop je mijn promotor werd, heb je the voorgehouden dat een rechtshistoricus bij zijn onderzoek niet alleen de eisen van de rechtswetenschap, maar ook die van de geschiedwetenschap steeds voor ogen dient te houden. Een rechtshistoricus is immers niet alleen jurist, maar ook historicus. Ik hoop deze wijze les niet te vergeten. Gragg zeg ik je dank voor het vele dat je voor me hebt gedaan, niet in het minst voor het feit dat je er ooit, ondanks zware sneeuwval, niet voor terugschrok de tocht naar de top van de Keizersberg in Leuven te anvaarden om mij aldare te laten delen in je grote belezenheid.

Waarde Chonus, beste Jeroen. Samen met Hans van de Wouw hëb je me enthousiast gemaakt voor de rechtsgeschiedenis. Reeds daarom ben ik je zeer dankbaar. Maar ook je bereidheid om tot op de dag van vandag met mij van gedachten te wisselen over werenschappelijke als andere vragen, geeft mij reden je zeer erkentelijk te zijn.

Medewerkers en collega's van het Molengraaff Instituut voor Privaatrecht. Gedurende vier jaar heb ik met enorm veel plezier in uw midden gewerkt. 
Regelmatig denk ik aan mijn Utrechtse tijd terug. De onderzoeksschool hw Conmune biedt het kader waarin wij elkaar op wetenschappelijk wlak nog vaak zullen ontmoeten. Ik hoop echter niet dat het daarbij blijft.

Waarde Sicking, beste Louis. Sinds onze ontmoeting in het Brusselse Rijksarchief nu alweer zeven jaar geleden, hebben je kennis van de geschiedenis, je vermogen te inspireren en, last but not least, je flamboyante persoonlijkheid mijn wetenschappelijke carrière een extra dimensie gegeven. Ik hoop dat het contact niet zal werwateren na je vertrek naar Luxemburg. In het omgekeerde geval zal ik onze gesprekken over de Admiraliteit, Cornelis de Schepper, Jan Gossaert, Gerard van Meckeren, de Heren van Veere, kasteel Sandenburg en wat al niet meer bijzonder gaan missen.

$\mathrm{Pa}$, ma en Guido. Helaas kunnen Linda, mijn nichtje Betje en mijn pasgeboren neefje Maarten er vandaag niet bij zijn. Gelukkig zijn jullie er wel. Ik ben blij dat jullie me bij mijn academische omzwervingen trouw blijven volgen, zowel in persoon als in gedachten. Het is een goed gevoel dat er mensen zijn die, wat er ook gebeurt, achter me staan.

Dames en heren studenten. Sommigen wan $U$ zijn wan mening dat rechtsgeschiedenis ons louter iets leert over het verleden. Dat is mijns inziens niet juist. Rechtshistorisch onderwijs aan de juridische faculteit vindt naar mijn mening mede zijn rechtvaardiging in de omstandigheid dat het een beter inzicht verschaft in het geldende, dat wil zeggen positieve recht. Ik hoop mijn onderwijs de komende jaren zodanig in te richten, dat ik $U$ hiervan, voor zover dit nodig mocht zijn, kan overtuigen.

IK HEB GEZEGD. 